\title{
TIPOLOGI TENDA SEBAGAI STUDI ARSITEKTUR PORTABEL
}

\author{
Rudy Trisno ${ }^{1}$, Fermanto Lianto ${ }^{2}$, Mieke Choandi ${ }^{3}$ \\ ${ }^{1}$ Jurusan Teknik Arsitektur dan Perencanaan, Universitas Tarumanagara Jakarta \\ Email: rudyt@ft.untar.ac.id \\ 2 Jurusan Teknik Arsitektur dan Perencanaan, Universitas Tarumanagara Jakarta \\ Email:fermantol@ft.untar.ac.id \\ ${ }^{3}$ Jurusan Teknik Arsitektur dan Perencanaan, Universitas Tarumanagara Jakarta \\ Email:mieke@ft.untar.ac.id
}

Masuk: 22-08-2021, revisi: 05-10-2021, diterima untuk diterbitkan: 06-10-2021

\begin{abstract}
ABSTRAK
Latar belakang penelitian adalah fenomena tren arsitektur dunia yang mulai mempertanyakan alternatif lain keruangan. Permasalahannya pada dekade terakhir arsitektur dunia didominasi oleh pemahaman ruang permanen pada makna arsitektur yang seolah bersifat absolut, padahal belakangan konsep-konsep keruangan temporal, ephemeral dan informal semakin dibutuhkan untuk mengisi stagnansi arsitektur permanen. Kebutuhan ruang portabel meningkat; hal ini terbukti dari tingginya permintaan akan: instalasi, paviliun, pop-up store, kontainer dan jenis keruangan lain yang lebih ringan, cair dan mudah dimodifikasi. Tenda adalah salah satu alternatif keruangan temporal yang telah berkembang sejak dulu kala, keunggulannya sebagai arsitektur portabel masih relevan di saat ini. Meski demikian, belum banyak perkembangan dan penelitian tenda yang berfokus pada tipe dan struktur untuk gaya hidup masa depan, sementara dominasi pengembangan tenda adalah untuk kebutuhan berkemah atau liburan saja. Penelitian ini bertujuan untuk menginvestigasi tipologi tenda sebagai arsitektur portabel Metode penelitian adalah tipologi arsitektur untuk mengangkat kualitas arsitektur tenda. Diagram arsitektur digunakan untuk menghasilkan ilustrasi yang dapat diinterpretasikan dalam memahami pola struktur tenda, Langkah penelitian sebagai berikut: 1) menggambar diagram keruangan; 2) mengekstraksi pola; 3) menginterpretasi pola. Tahapan penelitian disusun sebagai berikut: 1) Mengeliminasi elaborasi dan dekorasi tenda, 2) Mengekstraksi struktur tenda, 3) Menggambar pola. Hasilnya adalah diagram arsitektur tipologi tenda. Kebaruannya adalah ekstraksi pola dasar tenda sebagai arsitektur portabel.
\end{abstract}

Kata Kunci: Arsitektur; Portable; Tenda; Tipe; Tipologi.

\begin{abstract}
Architecture trends are continuously searching for a new design alternative. If architecture is dominated by a permanent structure in the last decades, the latest trend suggests temporal, ephemeral, and informal architecture to emerge as the other alternative. While the world becomes complex, these other spatial forms are in demand, resulting in various installations, pop-up stores, container architecture, and portable, temporal architecture constructed throughout the cityscape. Its portability, elasticity, and fluidity have offered different human activity transformations compared to permanent architecture. Tent, one of the most popular portable architecture, has been used for myriad human activities, although fewer researches are found regarding the typology of the tent, which is considered beneficial to understand its transformation. The qualitative interpretive method is used to understand the typology of the contemporary tent. The diagram is utilized as a tool to investigate its form, structure, and physical appearance. The research steps are drawing a diagram, pattern extraction, and pattern interpretation. The phases are elimination of tent's elaboration and decoration, pattern structure extraction, pattern illustration. The result is tent typology diagram. The novelty is tent basic pattern extraction.
\end{abstract}

Keywords: Architecture; Portable; Tend; Type; Typology. 


\section{PENDAHULUAN}

\section{Latar Belakang}

Pada dekade terakhir, fenomena arsitektur dunia mulai muncul dalam mencari keruangan alternatif untuk mencari solusi atas stagnansi dan keterbatasan arsitektur konvensional. Bila pada dekade sebelumnya, arsitektur banyak dipahami sebagai keruangan yang bersifat terbatas, kaku, rigid dan formal; perubahan dan dinamika yang cepat menuntut lahirnya keruangan yang berbeda agar dapat mengisi atau melengkapi bangunan yang ada (Elmokadem, April 2018). Keruangan yang berbeda pada masa kini adalah keruangan yang dapat mengakomodasi perubahan, kecepatan, pergerakan, tren dan kehidupan berpindah (Anas, 2017). Keruangan sementara jenis ini perlu dapat bertransformasi, bahkan berevolusi dengan responsif agar dapat berpacu dengan waktu (gambar 1), khususnya untuk regenerasi (Olga, 2018).

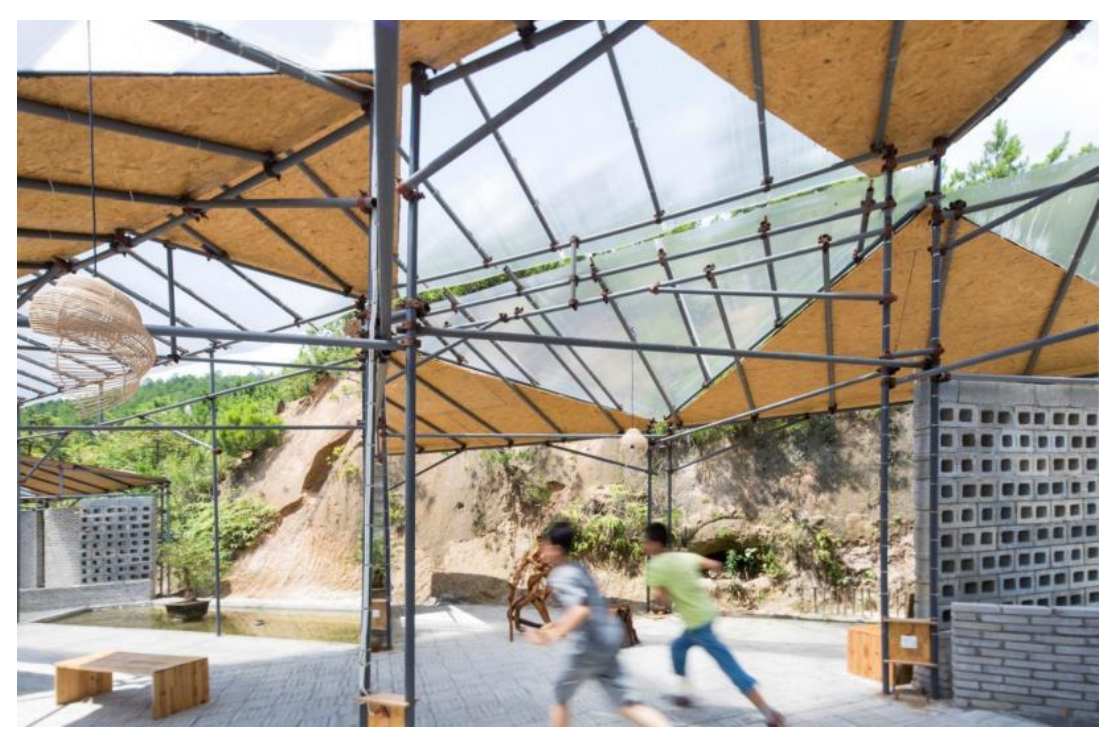

Gambar 1. Qianyi Farm oleh Big Smallness Studio + Wuhan ADAP Architects.

Sumber: https://www.archdaily.com/882001/the-temporary-workshop-and-recreationcentre-of- qianyi-farm-big-smallness-studio-plus-wuhan-adap-

architects/59e93132b22e384f140000f5-the- temporary-workshop-and-recreation-centre-ofqianyi-farm-big-smallness-studio-plus-wuhanadap-architects-image diunduh 8 September 2020.

Keruangan alternatif perlu menawarkan tipe yang berbeda dari yang umum; bila arsitektur secara konvensional dipersepsikan sebagai keruangan yang rigid, formal, statik dan permanen, keruangan alternatif yang banyak dikembangkan saat ini bersifat sementara, temporal, dinamis dan mudah berubah (Anas, 2017). Keruangan alternatif yang memiliki karakter ini salah satunya dikembangkan dari arsitektur portabel yang bersifat ringan, dapat ditekuk, diubah dan dibawabawa. Di seluruh dunia dan tersebar pada kondisi dan situasi yang berbeda, jenis arsitektur portabel berkembang dan kini telah melebur menjadi satu pada keruangan interior maupun eksterior melalui teknologi (Dias, 2018). Tujuan keruangan portabel adalah untuk mengisi celahcelah kebutuhan keruangan yang lain (gambar 2), termasuk untuk produktivitas generasi selanjutnya (Pyöriä, January-March 2017). 


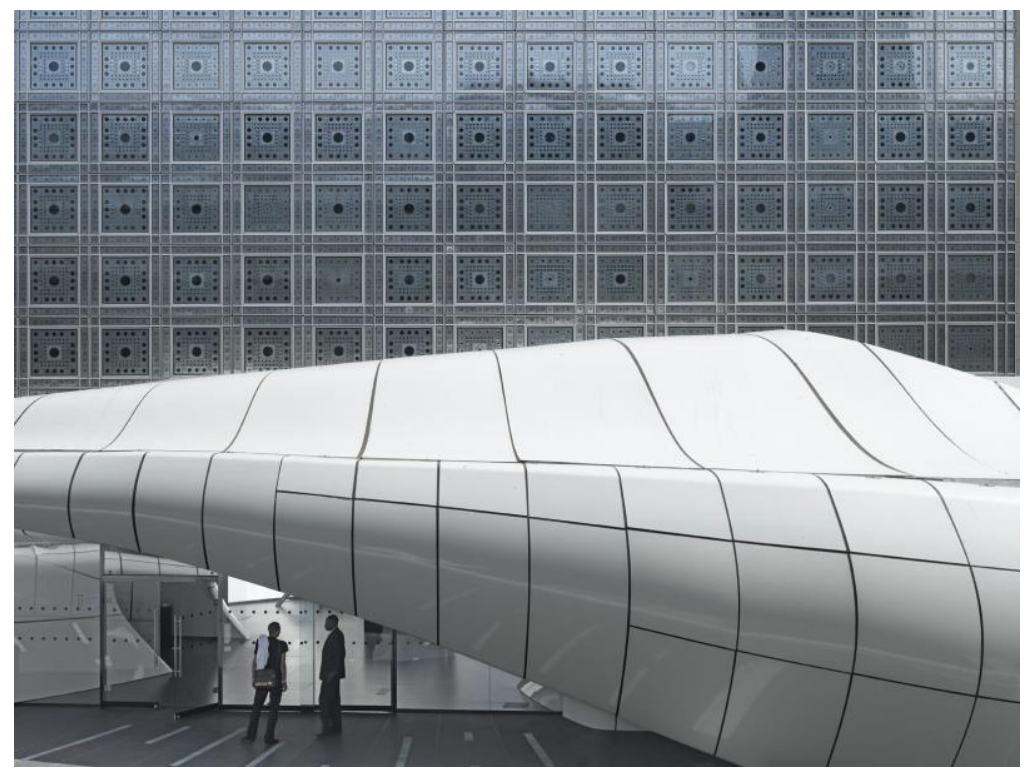

Gambar 2. Paviliun Chanel oleh Zaha Hadid Architects.

Sumber: https://www.zaha-hadid.com/wp-content/uploads/2019/12/zha_rolandhalbe_paris4.jpg diunduh 8 September 2020.

Ruang dalam maupun ruang luar pada masa kini diwarnai oleh bentuk, tipe dan struktur keruangan yang baru. Entah berbentuk instalasi, paviliun, kios, booth, tenda maupun yang melebur bersama lansekap di luar ruangan; pengguna diberikan alternatif ruang-ruang yang mudah dipindahkan, dimodifikasi, digerakkan bahkan dibawa-bawa sesuai dengan program, fungsi maupun acara yang diadakan dalam sebuah bangunan (Elmokadem, April 2018). Ruangruang tersebut ada yang mengakomodasi kebutuhan personal, ada yang menstimulasi partisipasi kelompok, ada yang bercampur dengan ruang sosial dan ada pula yang mempertanyakan kepublikan. Ruang-ruang temporal ini sudah menjadi ruang keseharian yang kita gunakan dalam keseharian (gambar 3).

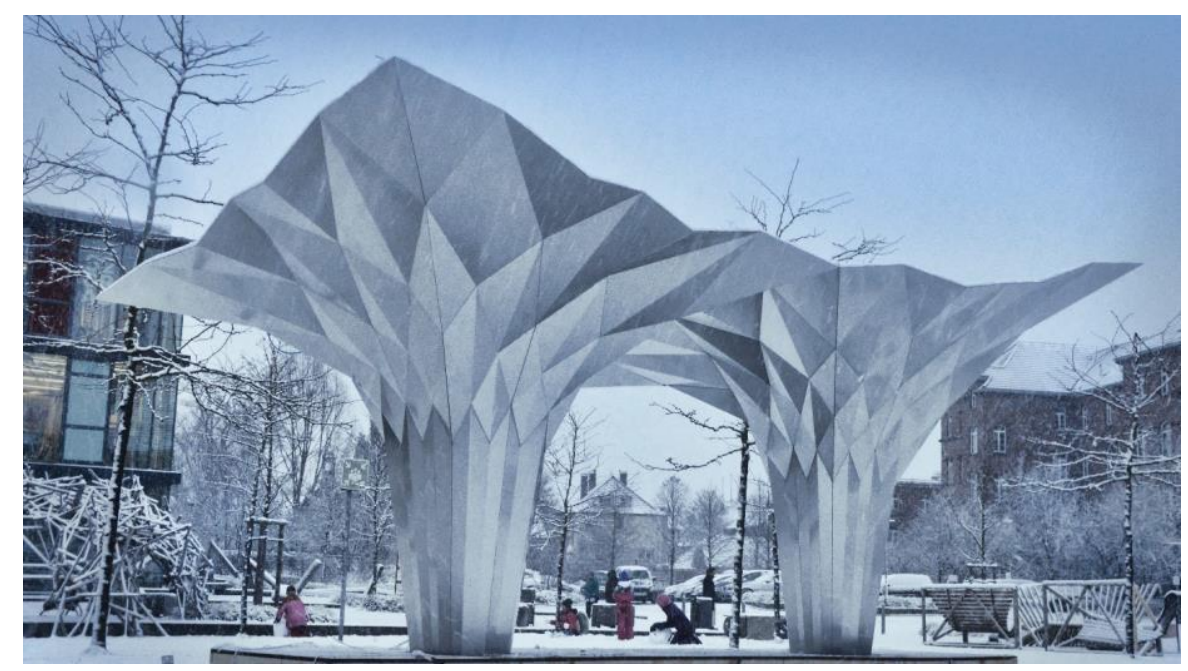

Gambar 3. Struktur Temporal pada Ruang Keseharian didesain oleh Tal Friedman. Sumber: https://pro2-bar-s3-cdncf1.myportfolio.com/a79915da1ba64d4224c10c86065850d5/24f07ad9bdee11df55211aa8_rw_3 840.jpg?h=838be71a877aa9f779dc38425229fc38 diunduh 8 September 2020. 
Ruang-ruang temporal ini mudah untuk dibongkar pasang, dikemas, dikirim dan didaurulang sehingga banyak yang berpendapat, arsitektur bersifat sementara ini erat hubungannya dengan arsitektur portabel dan berpotensi dikembangkan untuk ruang masa depan yang berkelanjutan (gambar 4). Ruang-ruang temporal memiliki potensi yang berbeda bila dibandingkan arsitektur permanen. Ruang temporal juga tidak dapat menggantikan kestabilan dan keajegan arsitektur permanen, namun demikian dapat melengkapi dan menyempurnakan arsitektur permanen, sehingga membentuk simbiosis mutualisme. Bila diskursus arsitektur pada dekade sebelumnya cenderung belum menganggap keruangan temporal sejajar dengan arsitektur, kini kombinasi keduanya tidak dapat dipisahkan.

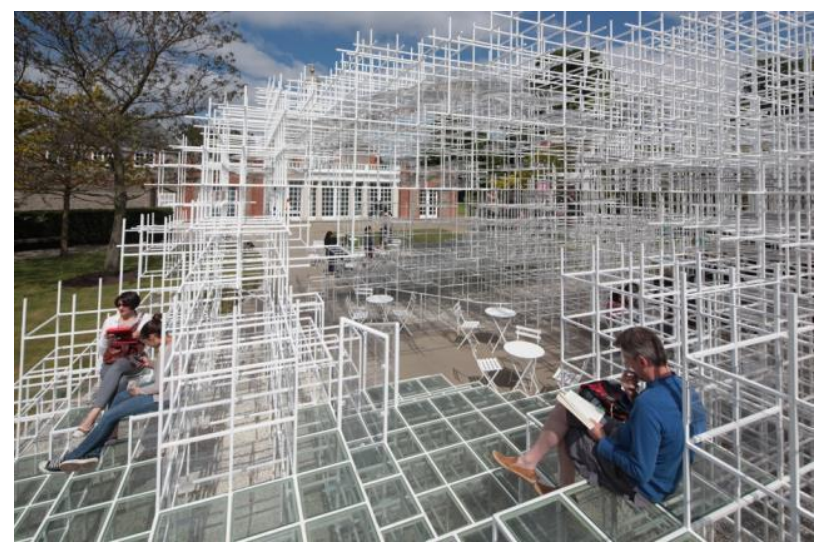

Gambar 4. Pavilion pada Galeri Serpentine, London oleh Sou Fujimoto.

Sumber: https://www.detail-online.com/fileadmin/_migrated/pics/Fujimoto_Serpentine15.JPG diunduh 8 September 2020

Keruangan temporal tidak muncul belakangan, kehadirannya sudah ada bahkan ketika arsitektur itu diciptakan. Banyak ahli percaya bahwa arsitektur temporal merupakan arsitektur primitif yang lahir saat kehidupan berpindah (gambar 5). Beberapa bahkan yakin korelasi antara arsitektur temporal terkait dengan arsitektur portabel, khususnya arsitektur tenda. Keruangan temporal dipercaya terjadi karena kemampuannya berpindah dan dibawa-bawa; maka dari itu kerap diasosiasikan dengan makna portabel. Kata portabel sendiri berasosiasi dengan mobile, temporal, ephemeral, informal, movable, transportable, lightweight, compact, small, minimal, highdensity pada ranah arsitektur, meskipun mungkin dapat berkorelasi dengan arti lainnya pada bidang lain.

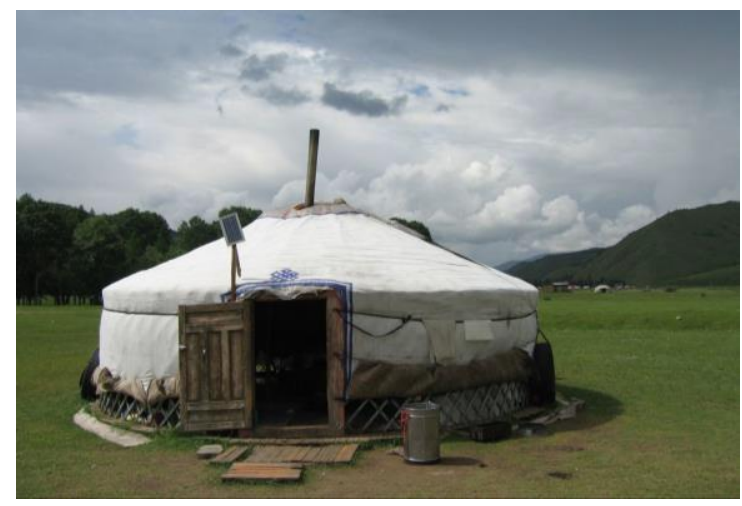

Gambar 5. Yurt, Tenda sebagai Ruang Kehidupan Berpindah di Mongolia Sumber: https://media.nationalgeographic.org/assets/photos/000/206/20672.jpg diunduh 8

September 2020. 


\section{a. Tipologi sebagai Keilmuan Arsitektur}

Tipologi sesungguhnya merupakan keilmuan yang mempelajari pengelompokan berdasarkan jenis atau tipe. Studi tipe adalah sebuah rangkaian sistematis yang dibentuk berdasarkan proses klasifikasi, yang dibangun berdasarkan karakteristik fisik yang sama. Secara etimologi, tipologi berasal dari kata Yunani yakni typos (tipe) dan logos (ilmu) yang mencerminkan relasi doktrin denagan simbol (gambar 6). Maka dari itu secara harafiah, tipologi dapat berarti: 1) keilmuan terkait dengan representasi simbol khususnya yang berhubungan linguistik, 2) klasifikasi sistematik bentuk fisik berdasarkan karakteristik yang sama, 3) hasil pengklasifikasian dari karakter yang serupa, 4) klasifikasi bahasa dan turunannya, 5) tipe dan figur dari tulisan. Maka dari itu tipologi berpusat pada bentuk, struktur dan fisik tertentu.

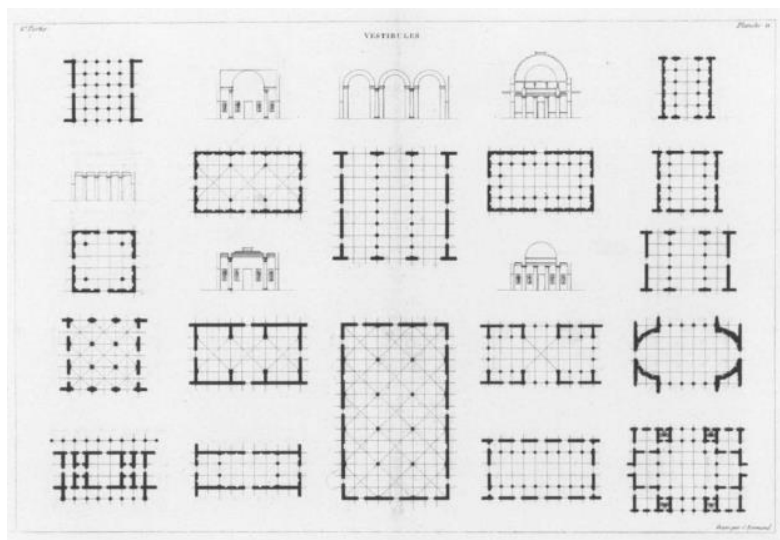

Gambar 6. Tipe dalam Arsitektur pada Precis des leçons d'Architecture oleh JNL Durand. Sumber: https://medium.com/@tlukejones/on-the-three-typologies-ed0b5747fd9c diunduh 8 September 2020.

Meskipun tipologi digunakan pada cabang ilmu yang berbeda-beda, pada keilmuan arsitektur tipologi diterjemahkan sebagai klasifikasi fisik bangunan yang ditentukan berdasarkan karakteristik umum yang ditemukan pada bangunan, khususnya pada konteks perkotaan (gambar 7). Karakter fisik bangunan diasosiasikan dengan kategori fungsi bangunan pada konteks perkotaan dan penyebarannya diatur berdasarkan tingkat, lokasi dan kebutuhan intensitas pembangunan tertentu. Maka dari itu, aturan yang dikembangkan dalam tipologi mempertimbangkan pengaturan bangunan untuk konteks tertentu: daerah alami, pedesaan dan perkotaan dan memiliki karakter fisik yang spesifik atau didominasi oleh tipe tertentu.

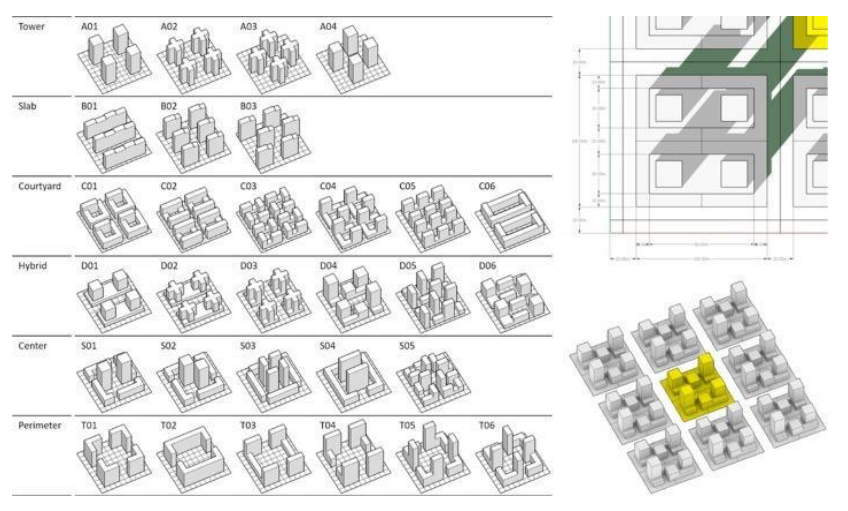

Gambar 7. Variasi Tipe pada Sebuah Konteks Perkotaan

Sumber: https://ars.els-cdn.com/content/image/1-s2.0-S0306261919303319-gr3.jpg diunduh 8

September 2020 diunduh 8 September 2020 
Tipologi pada ranah arsitektur berpusat pada logika penampilan dan penampakan struktur fisik bangunan yang terbentuk atau dibentuk oleh fakta dan alasan tertentu. Tipologi arsitektur membangun logika pembentukan jenis bangunan, berdasarkan fitur yang diwakili oleh karakter komposisi, aturan dan penataan sebuah bangunan. Elemen dan komponen fisik mewakili karakter pada tipe dan bersifat spesifik pada konteks lingkungan tertentu. Namun demikian, tipe juga memegang benang merah berdasarkan pola yakni persamaan antara yang satu dengan lainnya. Sebuah tipe bangunan tertentu bukan tidak mungkin berkorelasi dengan tipe lain pada konteks yang berbeda, sementara menunjukkan identititas khasnya. Oleh karena itu tipologi sebagai studi berpotensi mengangkat pola arsitektur tenda yang menekankan aspek utama pembentuk keruangannya.

\section{b. Tenda sebagai Arsitektur Temporal}

Tenda sebagai bentuk keruangan dikenal sejak dulu kala, namun demikian istilah tenda baru mulai dikenal pada tahun 1300an. Tenda pada masa itu didefinisikan sebagai pernaungan yang bersifat portabel dan terbuat dari kulit atau kain yang dibentangkan pada struktur berbentuk tiang. Meskipun arsitektur tenda berkembang di negara yang berbeda-beda, kata tenda sebenarnya dipopulerkan oleh istilah Prancis kuno tente yang secara literal berarti tenda, gantungan atau anyaman. Kata populer ini diduga berakar dari kata Latin abad pertengahan yakni kata tenta, yang maknanya tenda sebagai sesuatu yang ditarik atau dibentangkan, tentus adalah kata ditarik pada istilah latin atau tendere yang artinya untuk ditarik (gambar 8).

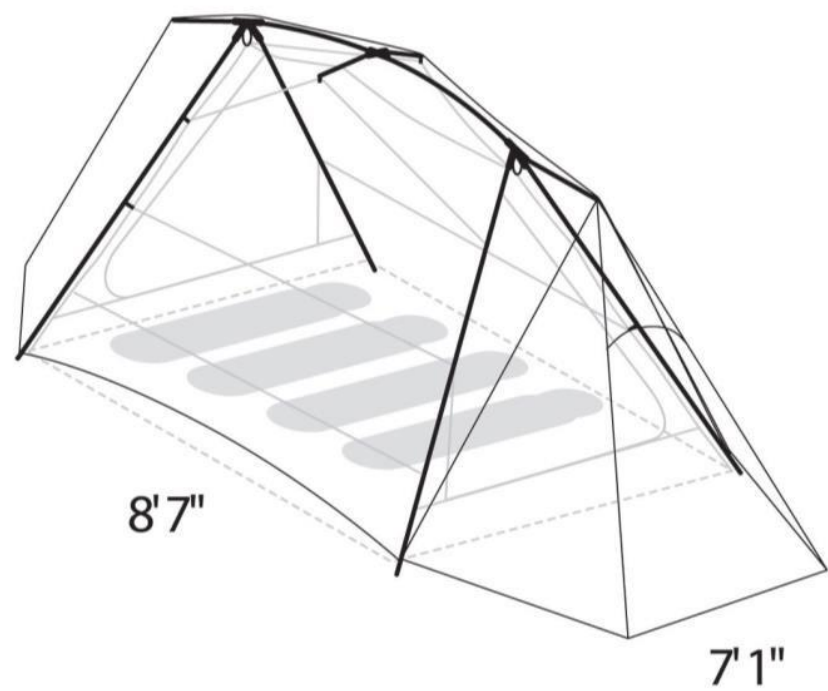

Gambar 8. Tenda sebagai Pernaungan dari Kain yang Ditarik dan Disanggah oleh Struktur

Sumber: https://eurekacamping.johnsonoutdoors.com/sites/johnsonoutdoorsstore/files/assets/images/10/1/1032641_detail10/1032641_detail10.jpg diunduh 8 September 2020.

Akar kata tenda yang berarti ditarik inilah yang banyak membangun relasi dengan arsitektur berkarakter portabel dan bersifat sementara. Ide membangun ruang dengan cara ditarik memang telah hilang dari pemahaman awam, namun demikian tenda sebagai struktur keruangan temporal masih menjadi salah satu keruangan yang mengisi gaya hidup masa kini (Abuin, 2004). Menilik makna sesungguhnya dari kata tenda, pernaungan yang disuguhkan oleh keruangan temporal jenis ini didasari oleh keruangan yang dibentuk pelingkup. Kata ditarik mewakili material lunak yang bersifat plastis, elastis dan tipis, namun karena keplastisannya tenda tidak dapat dipisahkan dari struktur sebagai pengatur pembentukannya (gambar 9). 


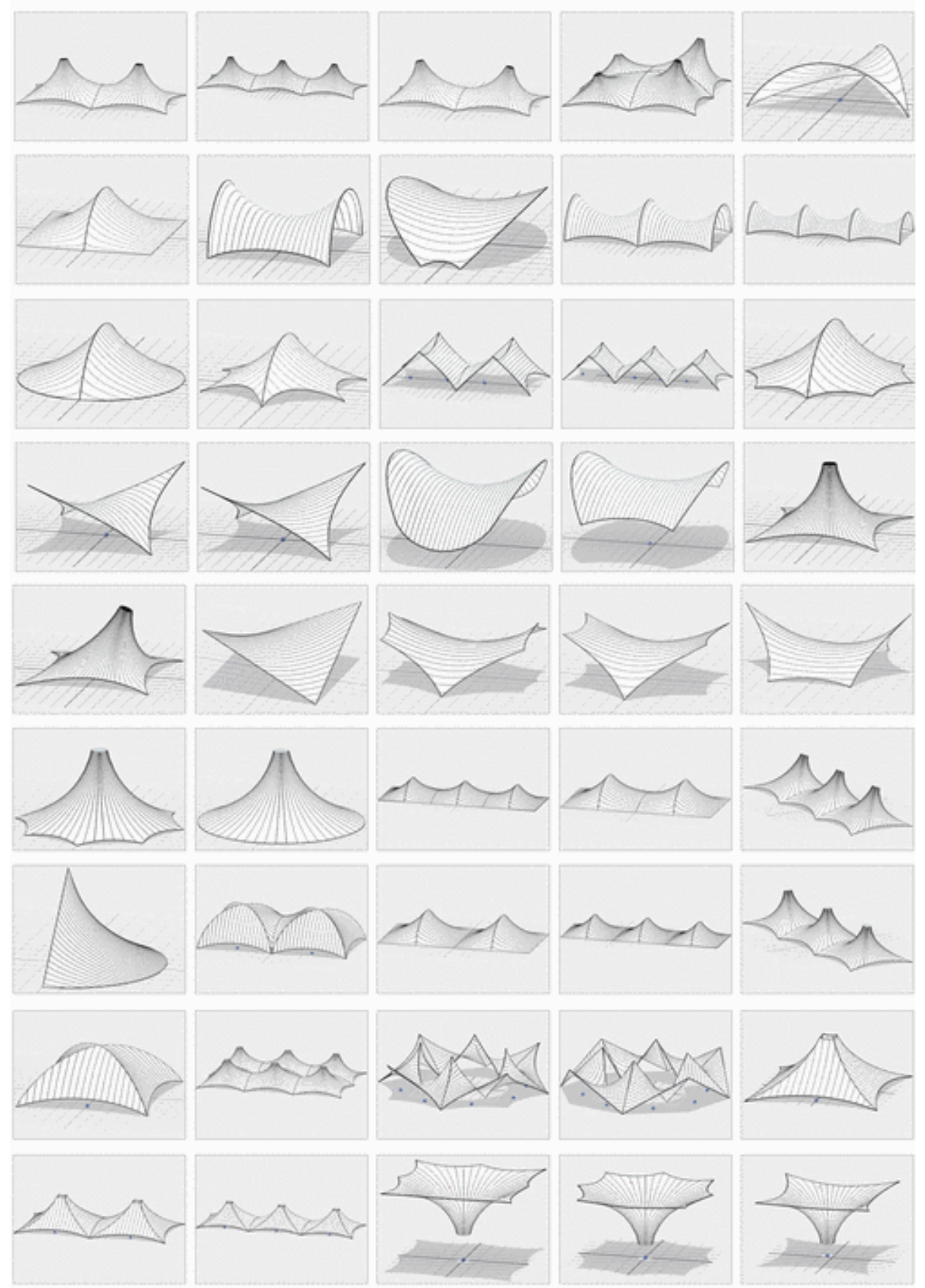

Gambar 9. Tipe-Tipe Tenda.

Sumber: https://i.pinimg.com/originals/5c/cb/fd/5ccbfd76ab9d1f1f584c98ee90173c78.png diunduh 8 September 2020.

Terdapat berbagai jenis tenda yang terdapat di pasaran, tenda-tenda komersial dikembangkan berdasarkan ide keruangan tenda primordial yang disesuaikan dengan kebutuhan jaman. Lepas dari bentuk dan model yang berbeda-beda, variasi fisik tenda pada dasarnya sangat tergantung pada komposisi struktur karena keplastisan material pelingkup tenda. Plastisitas inilah yang melingkupi struktur yang terdapat di dalamnya, struktur yang membagi keruangan dan menopang beban pelingkup sehingga terciptanya ruang pernaungan. Maka dari itu, fisik tenda secara mendasar terdiri dari dua material utama: pelingkup berupa fabrik dan struktur ringan yang menjadi aspek terpenting pada pola pembentuk ruang tenda (Ghaffar, 2019) (gambar 10). 


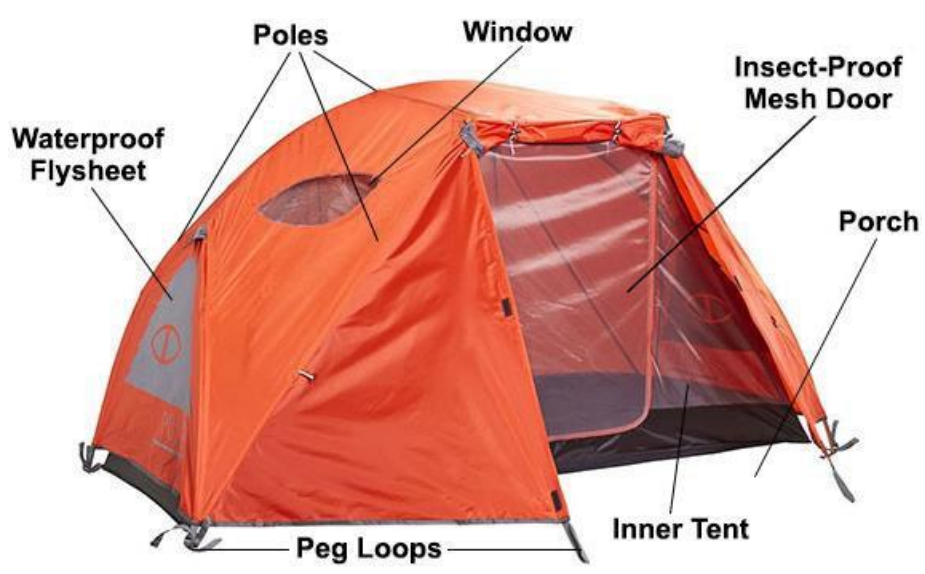

Gambar 10. Tenda Terdiri dari Dua Material Utama Struktur dan Pelingkup.

Sumber: https://www.absolute-snow.co.uk/pages/Tents/Tent-Diagram.jpg diunduh 8 September 2020.

\section{c. Arsitektur Portabel sebagai Arsitektur Nomaden yang Baru}

Kata portabel mungkin baru dikenal pada abad-14, sebagai kata Perancis kuno dan merujuk kata sifat portatif yang berarti desain sebagai proses perencanaan sebuah produk yang dapat dibawa ke tempat yang berbeda. Kata ini melahirkan kata portability yang menekankan pada kemampuan objek yang didesain. Di awal abad ke-15, Perancis menggunakan kata portable pertama kali, yang bermakna: dapat dibawa, yang terinspirasi oleh kata Latin portabilis, portare. Meski kata portabel baru diperkenalkan di abad ke-15, konsep portabel dikenal sejak pra sejarah, khususnya pada struktur tenda untuk kebutuhan ruang kehidupan berpindah dan berkembang menjadi lebih kompleks pada masa kini (Abuin, 2004).

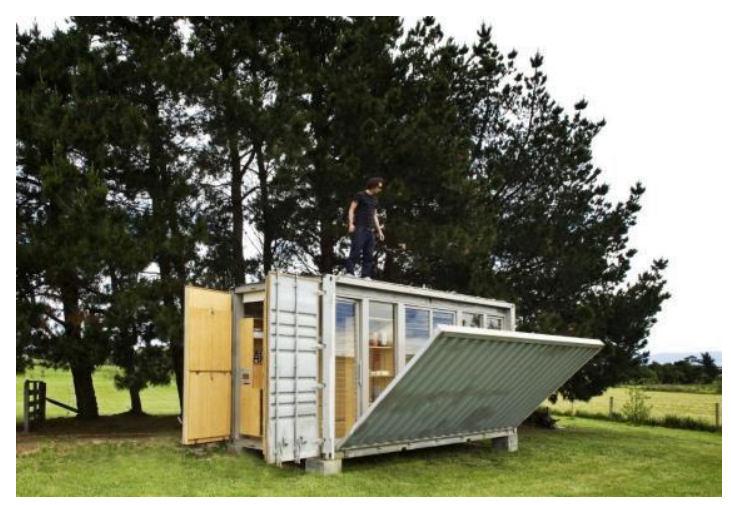

Gambar 11. Arsitektur Portabel Masa Kini.

Sumber: https://www.arch2o.com/wp-content/uploads/2017/11/Arch2O-PortableHomes-9.jpg diunduh 8 September 2020.

Arsitektur portabel sering diasosiasikan dengan kemampuan demontable dan transportable. Sebagai bagian dari gaya hidup masa kini, arsitektur portabel terbangun karena kebutuhan tertentu. Kemampuan portabel direncanakan untuk acara tertentu agar ruang dapat dipindahkan atau alokasikan, karena status bangunan tidak bersifat permanen. Arsitektur portabel merujuk pada aspek produksi keruangan yang mempertimbangkan efek berkelanjutan dan materi perduli lingkungan. Pada kenyataannya penggunaan kembali, kemampuan untuk dirakit dan dibongkarlah yang menempatkan arsitektur portabel dapat bersifat reuse/usable (dapat digunakan kembali) dan recyle (dapat didaur ulang) (Rathi, Augustus 2017). 


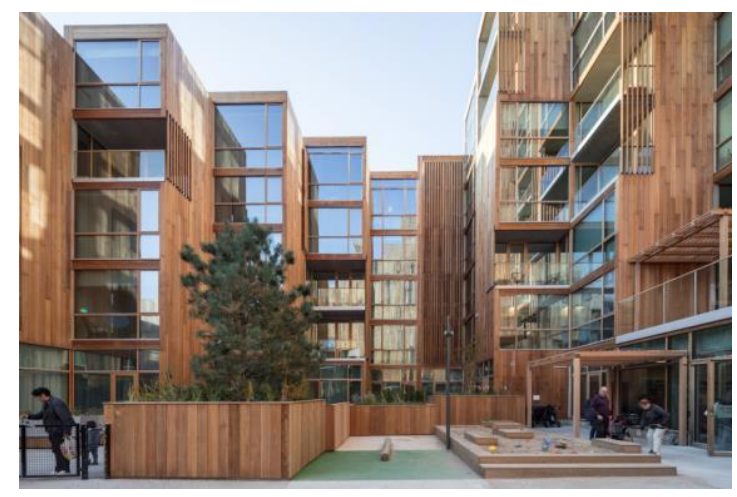

Gambar 12. Pengembangan Arsitektur Portabel menjadi Arsitektur Permanen. Sumber: https://www.architecturequote.com/wp-content/uploads/2019/12/modular-architectureand-wood-1024x683.png diunduh 8 September 2020.

Pertimbangan akan kemampuan berpindah mendorong pentingnya penelitian spesifik dari sisi ukuran, struktur ringan, fleksibilitas sendi, metode pengemasan, dan kemudahan untuk digunakan. Maka dari itu, banyak ahli berpendapat bahwa arsitektur portabel dekat dengan keberlanjutan karena dianggap sifatnya yang temporal meminimalisasi kerusakan permukaan bumi (we-a, 2019). Pada kehidupan saat ini dari kantor formal, akomodasi, pujasera, kamar mandi (gambar 13) bahkan fasilitas relaksasi banyak menggunakan ruang portabel. Ruang-ruang ini dibentuk oleh elemen-elemen dan komponen-komponen ruang yang bersifat modular dan berfokus pada unit, meskipun pada implementasinya di Indonesia sangat jarang diaplikasikan secara total.

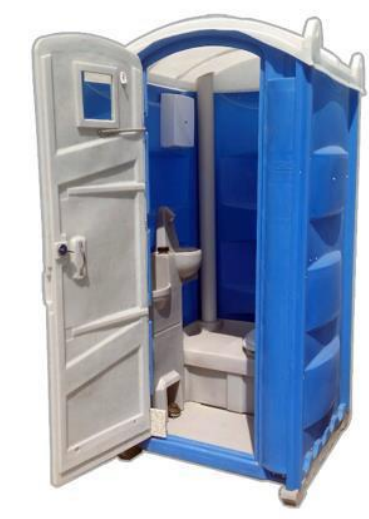

Gambar 13. Ruang Portabel Temporal di Kehidupan Sehari-hari.

Sumber: https://sc02.alicdn.com/kf/UTB81SAUI4HEXKJk43Je761eeXXas.png diunduh 8 September 2020.

Namun demikian, pemahaman umum tentang arsitektur portabel lebih banyak didominasi oleh konsepsi ruang sementara untuk kebutuhan liburan (gambar 14). Sebut saja: tenda, pernaungan, pondokan, karavan dan rumah apung lebih mendekati ide tentang arsitektur portabel; meskipun implementasinya lekat dengan keseharian kita (Rathi, Augustus 2017). Pada beberapa tahun terakhir, sebut saja booth, kios, kontainer, ruang bermain, paviliun menjadi trending pada bangunan publik seperti Mall. Belum lagi kantor, studio, rumah sangat sederhana, rumah bencana dan ruang tematik banyak mengimplentasi konsep portabel. Baik untuk kebutuhan komersial ataupun sosial, arsitektur portabel telah menjadi ruang keseharian yang bersifat termporal maupun semi-permanen, namun sedikit khalayak yang merujuk ruang-ruang temporal ini sebagai salah satu bentuk konkret dari arsitektur. 


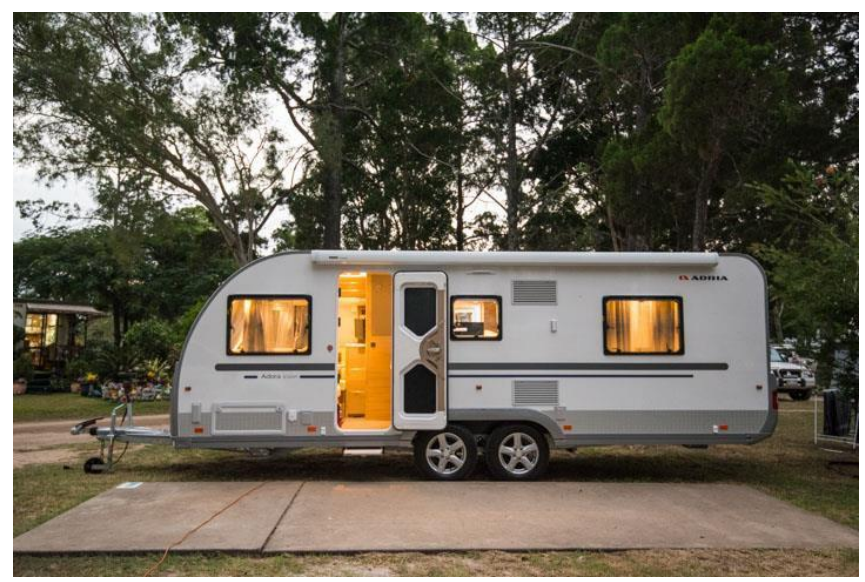

Gambar 14. Ruang Portabel Lekat dengan Fungsi Tamasya atau Resor.

Sumber: https://www.timetoroam.com.au/wp-content/uploads/2018/11/AdriaAdora612-10.jpg diunduh 8 September 2020.

Maka dari itu, konsep arsitektur portabel masih memiliki karakter dominan sebagai ruang untuk kebutuhan berpindah dan bersifat tersier, daripada menekankan potensi atau konsepsi temporal sebagai ruang penting dalam keseharian. Potensi arsitektur portabel pada tenda terbukti dapat mengikuti jaman dan perlu diangkat untuk membuka peluang-peluang baru, yakni sebagai keruangan yang berbeda dan dapat bersifat esensial daripada sekedar untuk kebutuhan khusus saja (Anas, 2017). Maka dari itu untuk memperoleh materi utama dari tenda, elemen dan komponen fundamental tenda perlu diinvestigasi melalui tipologi.

Dengan berfokus pada tipologi tenda, potensi portabel keruangan tenda akan dipertanyakan, khususnya terkait dua unsur utama ruang, yakni: struktur dan pelingkup yang mengilustrasikan karakter utama tenda. Karakter portabel tenda yang menjadi kekuatan temporal keruangannya akan dipertanyakan melalui investigasi fisik pada tipe-tipe tenda. Tipe-tipe tenda akan diurai untuk menunjukkan benang merah melalui pola yang sama sebagai kunci utama bentuk keruangan, sementara fleksibilitas dan peluang bentuk keruangan menjadi celah penelitian untuk mencari transformasi yang dapat terjadi pada tenda sebagai arsitektur portabel (gambar 15). Oleh karena itu pola dasar tenda akan diekstraksi menggunakan diagram arsitektur untuk menekankan tipologi yang berorientasi pada pelingkup dan struktur tenda sebagai pembentuk karakter temporal dan portabel pada arsitektur tenda.

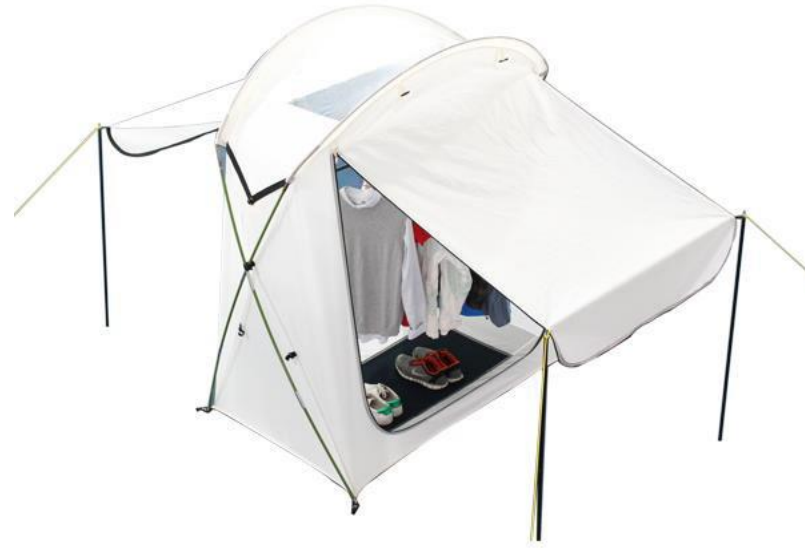

Gambar 15. Peluang Transformasi Tenda untuk Tipe Keruangan Berbeda.

Sumber: https://www.greencampabc.com/uploads/38a0b92311.jpg diunduh 8 September 2020. 


\section{Rumusan Masalah}

Tipologi tenda pada penelitian ini digunakan untuk menjawab masalah dalam pengkategorian tenda, menginvestigasi struktur, bentuk dan tampilan untuk menekankan kelebihan dan kekurangan tipe sehingga pertanyaan penelitian dirumuskan sebagai berikut:

a. Mengapa tipologi tenda diperlukan?

b. Bagaimana kategori dalam tipologi tenda?

c. Seperti apakah tipe-tipe tenda?

\section{METODE PENELITIAN}

Metode penelitian menggunakan metode kualitatif interpretatif dengan tipologi. Tipologi dikembangkan menjadi metode yang berfokus pada elemen fisik struktural yang membentuk keseluruhan bentuk keruangan, pada kasus tenda ditekankan pada struktur dan pelingkup tenda. Metode ini membandingkan tipe-tipe tenda yang berbeda-beda bentuk struktur dan pelingkupnya; untuk ditemukan pola, benang merah dan karakter uniknya. Dengan membandingkan, penelitian ini mencari peluang dan celah penelitian berupa transformasi dan celah terbentuknya ruang yang berbeda sebagai bentuk lain dari tenda sebagai arsitektur portabel.

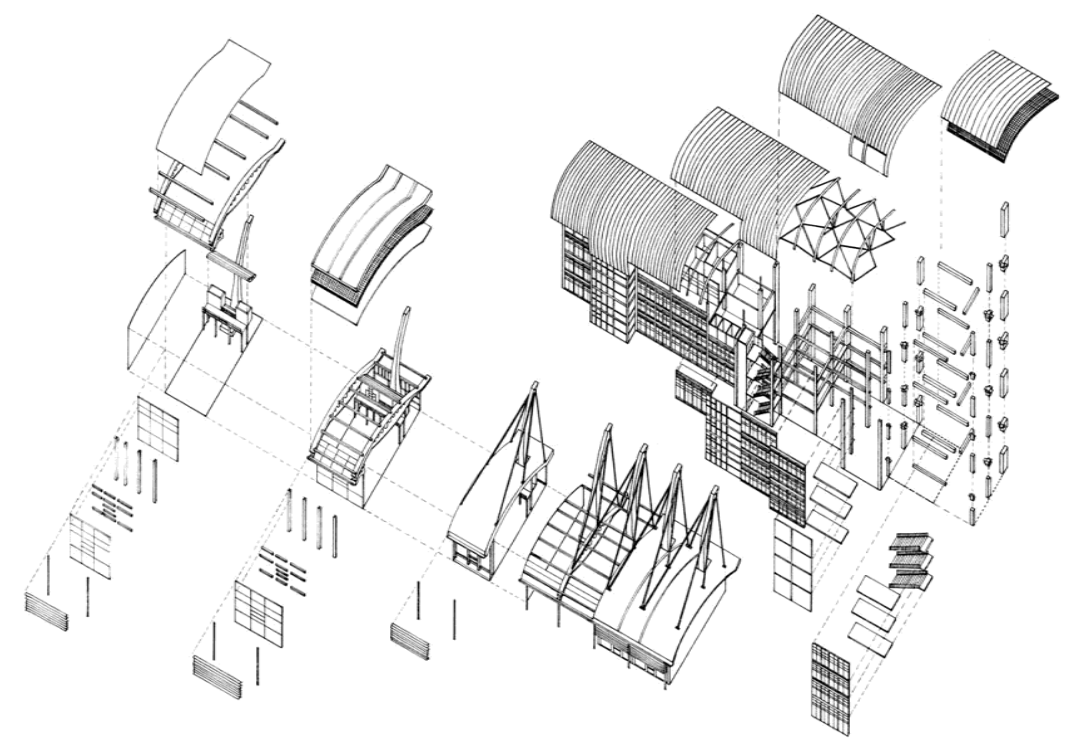

Gambar 16. Tipologi sebagai Metode.

Sumber: https://i2.wp.com/www.lifeofanarchitect.com/wp- content/uploads/2020/06/ExplodedAxo-Hand-Drawn.jpg?resize=1200\%2C832\&ssl=1 diunduh 8 September 2020.

Alat yang digunakan pada penelitian ini adalah diagram arsitektur. Diagram pada metode penelitian digunakan untuk menyederhanakan dan mengeliminasi elemen dekoratif atau ornamentatif pada tipe-tipe tenda untuk menekankan pada struktur dan pelingkup tenda sebagai elemen fundamental. Melalui sebuah penyederhanaan, tipe-tipe tenda direduksi menjadi elemen arsitektur terpentingnya saja untuk dibandingkan. Elemen fundamental tenda mengilustrasikan bagian paling esensial dari ruang yang direpresentasikan dalam bentuk formasi dan komposisi ruang, sehingga persamaan dan perbedaan struktural dapat terlihat dengan jelas. Penggunaan diagram dilakukan dengan langkah-langkah: 1) menggambar struktur keruangan, 2) mengekstraksi pola, 3) menginterpretasi pola. Tujuannya untuk menghasilkan struktur tenda kontemporer yang berfokus pada detail sebagai kunci fleksibilitas. 


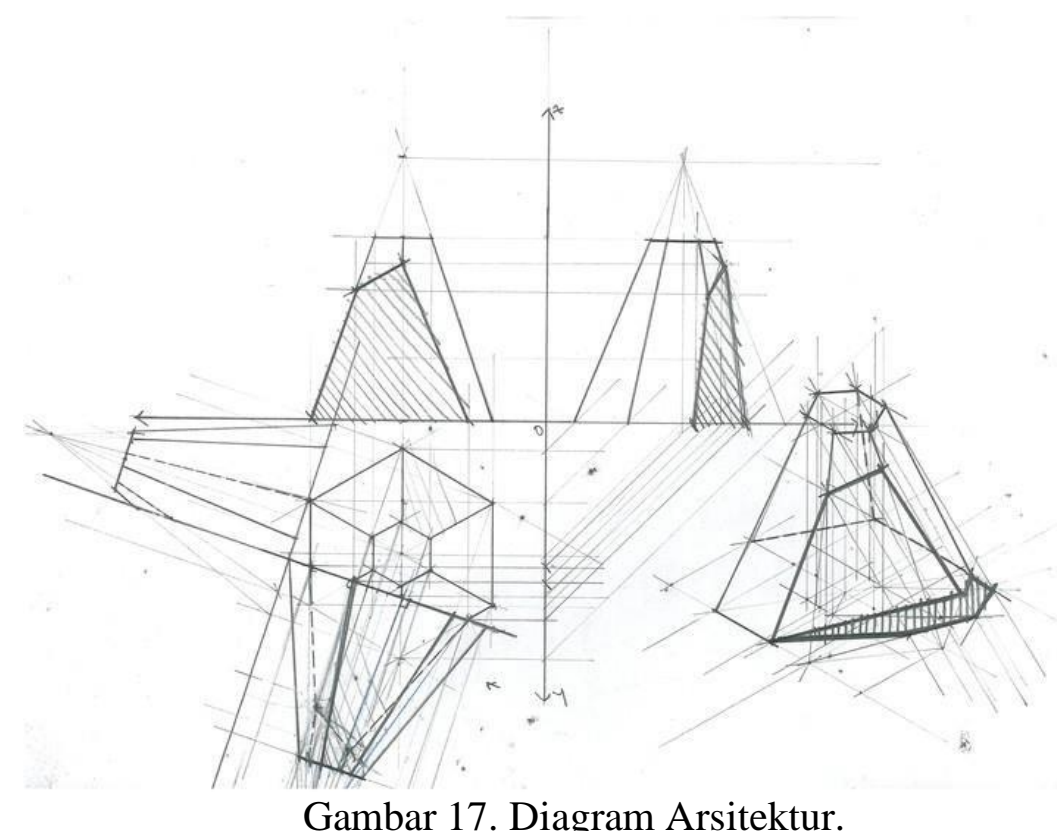

Sumber: https://i2.wp.com/www.lifeofanarchitect.com/wp- content/uploads/2020/06/ExplodedAxo-Hand-Drawn.jpg?resize=1200\%2C832\&ssl=1 diunduh 8 September 2020.

Tahapan peneltian secara umum berkonsentrasi pada studi tipologi tenda. Diagram digunakan sebagai alat penelitian untuk menginvestigasi, mengujicoba dan menjembatani teori dan praktis untuk menemukan bentuk paling sederhana tenda sebagai arsitektur portabel. Penelitian mendapatkan hasil analisis dari uji coba pada gambar arsitektur diimplementasikan untuk membangun relasi antara struktur dan pelingkup tenda.

\section{HASIL DAN PEMBAHASAN}

\section{a. Tipologi Tenda}

Tipologi tenda berfokus menginvestigasi struktur, bentuk dan tampilan, berakar pada kesejarahan dan transformasi tenda sehingga kehadiran tenda modern saling berkorelasi bahkan terkait dengan bentuk tenda primitif di masa lalu. Tenda berevolusi dari bentangan kain yang disanggah sampai membentuk struktur kompak yang kompleks. Tenda menawarkan kegiatan sederhana sampai rumit, hiburan sampai eksplorasi; namun demikian variasi yang ditawarkan kian mengarah kepada fungsi spesifik kegiatan manusia. Untuk memahami kompleksitas tenda sebagai arsitektur temporal, pendataan dengan metode tipologi menghantar penelitian kepada kategorisasi, membagi tipe berdasarkan bentuk, struktur dan fungsi. Melalui tipologi karakter tenda sebagai arsitektur mengurai kelebihan dan kekurangannya sehingga tenda berpotensi untuk disempurnakan sebagai keberlanjutan gaya hidup nomaden.

Terdapat setidaknya 25 tipe tenda yang dikenal pasar dan telah memiliki kestabilan. 25 tipe ini dapat dijumpai di pasaran dan dikenal sebagai tipe umum. Tipe umum dapat mewakili bentuk, fungsi, pengguna, detail struktur dan spesifikasi bervariasi. Melalui tipologi penelitian mengkategorisasi tenda berdasarkan polanya membagi kategori tenda sebagai berikut: 15 tipe tenda dengan fungsi terdepan, 9 tenda dengan model sesuai dengan gaya hidup, 6 bentuk utama yang berkembang secara ajeg dan 3 bentuk dasar tenda. Lepas dari variasi tenda yang digunakan secara umum, tipologi menekankan pada pola dasar sehingga dapat disederhanakan. 
Replikasi dan multiplikasi tenda yang membuat pola dasar berkembang, dengan mengkombinasi bentuk, struktur dan tampilannya. Dengan transformasi tenda di masa depan dapat menghasilkan arsitektur temporal dengan kemungkinan yang tidak terbatas

Secara keseluruhan 25 tipe umum tenda yang dapat dijumpai terbagi menjadi 2, yakni tenda berdasarkan bentuk dan materialnya. Tipe berdasarkan bentuk yang dikenal di pasaran, adalah: ridge tent, dome tent, pop-up tent, tunnel tent, geodesic dan semi-geodesic tents, inflatable tent, backpacking tent, the vis a vis tent, pod-style tent, cabin tents, pyramid tent, bivy tents, hammock tent, bell tents, frame tent dan beach tent dan car-top tent ${ }^{l}$. Sementara tipe berdasarkan materialnya terdiri dari cotton/canvas, pvc-coated tents, polycotton, polyester, nylon, groundsheet fabric, tent poles dan peg materials ${ }^{2}$. Baik berdasarkan bentuk maupun material, keduanya menjadi tipe produk tenda yang dikenal publik dan digunakan karena fungsi spesifik atau disukai karena modelnya.

Tabel 1. Tipe-Tipe Tenda

Sumber: Dikumpulkan Trek Baron melalui blog, ditabulasikan oleh tim diunduh 2 November 2020
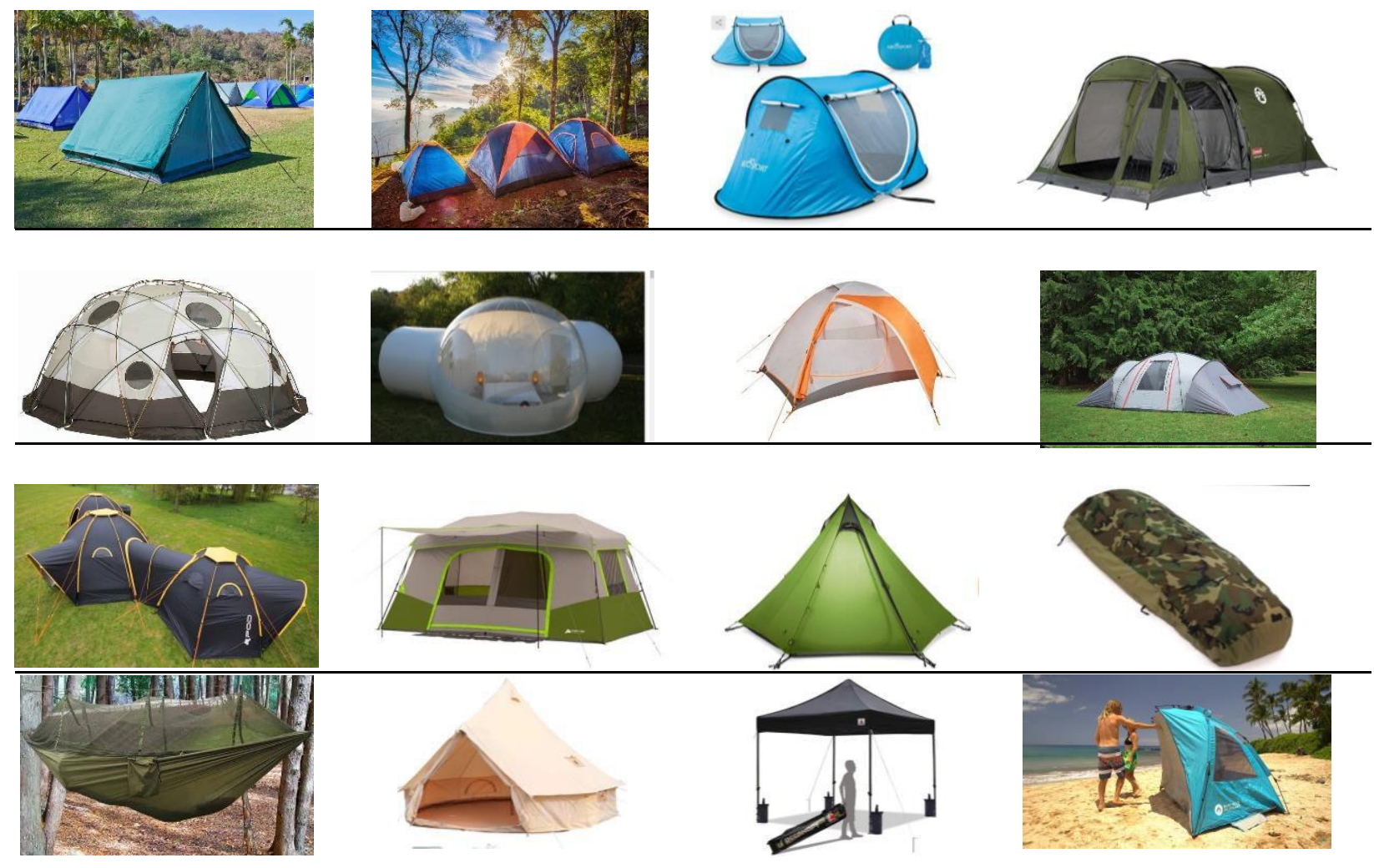

1 Car-top tent tidak dikategorikan sebagai tipe berbeda pada tipe umum karena perbedaan tidak memenuhi teori tipologi karena hanya terletak pada lokasi penempatan tenda, yakni pada dak mobil

2 https://trekbaron.com/types-of-tents/ 
Lima Belas tipe tenda dengan fungsi terdepan merupakan jenis tenda yang paling umum digunakan pada kehidupan sehari-hari, secara berurutan adalah sebagai berikut: dome tent, frame/wedge/ridge tent, geodesic/semi-geodesic tent, backpacking tent, multi-room tent, beach tent, hammock tent, cabin tent, pop-up/instant tent, inflatable tent, car top-roof tent, tunnel tent, teepee tent, bivvy tent, dan canopy tent ${ }^{3}$. Dengan tunnel, teepee, bivvy dan canopy merupakan bentuk turunan. Turunan merupakan hasil modifikasi atau imitasi dari bentukbentuk utama, namun dikembangkan secara khusus untuk kondisi spesifik. Namun demikian, ke 15 tipe ini dibedakan berdasarkan fungsinya, yakni kemudahan penyusunan, kestabilan, ketahanan terhadap kondisi cuaca, namun tidak terkait langsung dengan kategori berdasarkan tipologi.

Meski terdapat fungsi spesifik, hanya 9 tenda yang dikategorikan sebagai tipe yang memenuhi kebutuhan dasar untuk menunjang kehidupan pernaungan ${ }^{4} .9$ tenda ini dianggap cocok untuk mewadahi kehidupan temporal dalam waktu lebih lama karena memiliki bentuk ergonomis, struktur efektif, ringan serta memungkinkan produktivitas ruang lebih tinggi. 9 tipe ini meliputi dome tent, frame/wedge/ridge tent, multi room tent, backpacking tent, geodesic/semigeodesic tent, pop-up tent, tunnel tent, inflatable tent dan teepee tent. 9 tipe mewakili pentingnya perbedaan bentuk, struktur, fungsi dan kemudahan penggunaan untuk memenuhi kebutuhan dasar untuk jangka waktu lama, sementara tidak merujuk pada fungsi spesifik.

Proses kategorisasi dan seleksi merangkum tipologi tenda secara umum dapat dibagi menjadi: tipe tenda berdasarkan bentuk: ridge/frame/wedge, dome, tunnel, geodesic, cabin dan pyramid. Tenda dengan multi-fungsi/multi-member: multi room tent, inflatable dan pop-up/instant tent. Tenda untuk eksplorasi: backpacking, bivy and hammock. Tenda untuk gaya hidup: bell tent dan teepee tent. Tenda untuk kebutuhan khusus: canopy tent, beach tent, suspended tent dan roof top tent. Kategori memurnikan bentuk, struktur dan fungsi tenda, sehingga pembeli dengan mudah mengenali keunggulan dan kelemahan yang ditawarkan oleh masing-masing tipe.

\section{b. Arsitektur Tenda Temporal untuk Gaya Hidup Nomaden}

Dengan keutamaan pada bentuk dan struktur, tipologi menseleksi 6 bentuk yang menjadi bentuk utama tenda pada gaya hidup nomaden masa kini. Bentuk-bentuk populer ini perlu diurai sehingga dapat mengulas benang merah sebagai konsep utama pernaungan tenda. Sifat temporal tenda ditentukan oleh dua elemen utama, yakni: fleksibilitas struktur dan pelingkup untuk menunjang fungsi. Maka dari itu, struktur dan bentuk mempengaruhi karakter arsitektur temporal tenda. Bentuk utama yang dikenal di pasaran dijabarkan sebagai berikut:

Tipe ridge/frame/wedge merupakan tipe tenda paling ikonik yang dipersepsikan sebagai bentuk tenda yang dikenal umum. Dimensi umum $2135 \mathrm{~mm}$ x $2135 \mathrm{~mm}$ x $1838 \mathrm{~mm}(19 \mathrm{~kg}) 2745 \mathrm{~mm}$ x $2135 \mathrm{~mm}$ x $1938 \mathrm{~mm}(21 \mathrm{~kg})$ dan $3050 \mathrm{~mm}$ x $2440 \mathrm{~mm}$ x $2135(25 \mathrm{~kg})$. Secara tradisional tipe tenda ini terdiri dari kombinasi bentuk prisma dan/atau balok. Tenda ini dibangun dengan meletakkan tiang horizontal yang disanggah setidaknya oleh 4 buah tiang. Material yang umum dikenal adalah kanvas, namun kini penggunaan alumunium ringan dan waterproof polyester dan nylon juga sering digunakan. Kelebihannya adalah baik untuk menghadapi hujan, stabil untuk menghadapi angin dan sederhana untuk dipahami. Sementara kekurangannya adalah ruang kepala yang terbatas, umumnya lebih berat karena jumlah strukturnya dan tidak mudah untuk dibangun.

\footnotetext{
${ }^{3}$ https://outdoorwithj.com/types-of-tents/

${ }^{4} \mathrm{https}: / /$ arborexplorer.com/types-of-tents/
} 


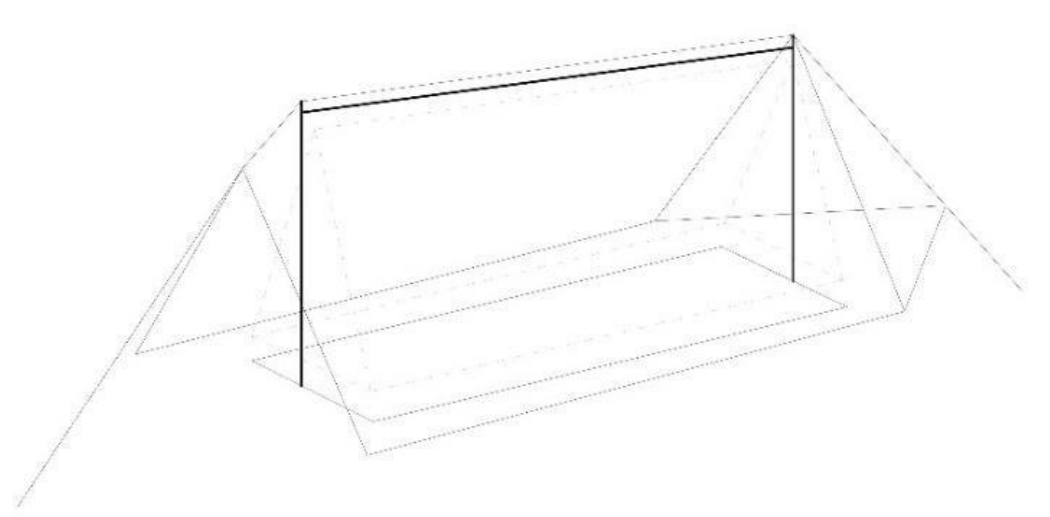

Gambar 18. Ridge Tent

Sumber: Penulis, 2020

Tipe dome adalah tipe paling umum yang digunakan. Dimensi umum $140 \mathrm{~mm}$ x $205 \mathrm{~mm}$ x 100 mm. Secara keseluruhan, tenda ini berbentuk kubah dan dibangun oleh dua buah struktur fleksibel yang saling bersilangan untuk membentuk pernaungan. Kedua struktur membengkok dan bersauh pada empat titik lantai yang terkunci. Struktur dapat terletak di luar tenda ataupun di dalam tenda sehingga berpotensi membentuk lebih dari 1 lapis pelingkup. Kelebihannya adalah relatif murah, mudah dibangun dan disimpan, ringan, ukuran kecil dan ruang kepala yang baik. Kekurangannya adalah kurang stabil pada kondisi cuaca berangin atau hujan, tidak stabil bila berukuran besar dan tidak memiliki atau berberanda kecil.

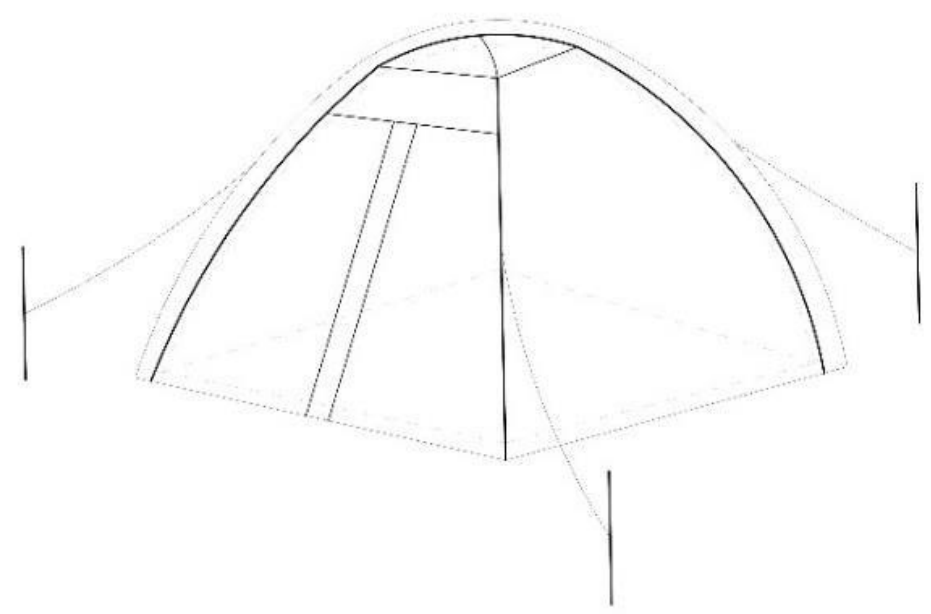

Gambar 19. Dome Tent

Sumber: Penulis, 2020

Tipe tunnel adalah jenis tenda umum kedua yang sering digunakan dan lebih banyak dipakai untuk kebutuhan kelompok atau keluarga. Dimensi umum adalah tipe $2800 \mathrm{~mm}$ dan 3600 mm sebagai ukuran lebar, dengan modul panjang: 190, 210, 230 dan $305 \mathrm{~mm}$ dengan tinggi di atas $1000 \mathrm{~mm}$. Secara umum, tenda ini berbentuk setengah silinder yang terdiri dari struktur fleksibel berupa rusuk yang disusun dan dirakit secara berangkai. Dengan struktur berseri, ruang yang dibangun menjadi terbagi untuk anggota berbeda dan memungkinkan penyambungan atau penambahan ruang. Kelebihannya adalah mudah untuk dibangun dan diurai, lebih banyak ruang untuk anggota, ruang kepala yang baik, cocok untuk kelompok, stabil bila diorientasikan menghindari arah angin. Kekurangannya cenderung berat, ukuran lebih besar dan tidak kuat dalam menghadapi air hujan. 


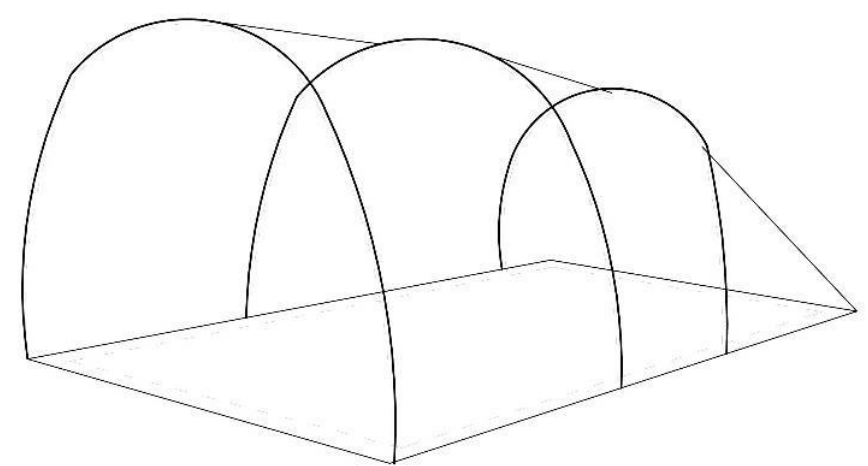

Gambar 20. Tunnel Tent

Sumber: Penulis, 2020

Tipe geodesic sesungguhnya merupakan penyempurnaan tipe dome yang dikhususkan untuk menghadapi cuara ekstrim. Dimensi umum diameter 6, 8, 10, 15, 20, 25, 30-meter dengan ketinggian 4, 5, 8, 10, 13, 15 meter. Maka dari itu meskipun secara umum tipe ini memiliki karakter dome, namun demikian jumlah struktur dan ekstensi ruangnya berguna untuk menstabilkan bentuk keseluruhan tenda sementara mentransformasikan tampilannya. Secara umum, transformasi yang terjadi bersifat struktural dengan ketebalan tiang dan jumlah silangan yang lebih banyak. Maka dari itu tipe ini cocok untuk eksplorasi di alam belantara, musim dingin atau medan yang ekstrim. Kelebihannya: sangat stabil baik untuk cuaca ganas, ketahanan yang tinggi dan mutu material yang bagus, ruang kepala yang baik dan umumnya ringan. Namun demikian memiliki kekurangan yakni mahal, rumit untuk dibangun dan terbatas jumlah penggunanya.

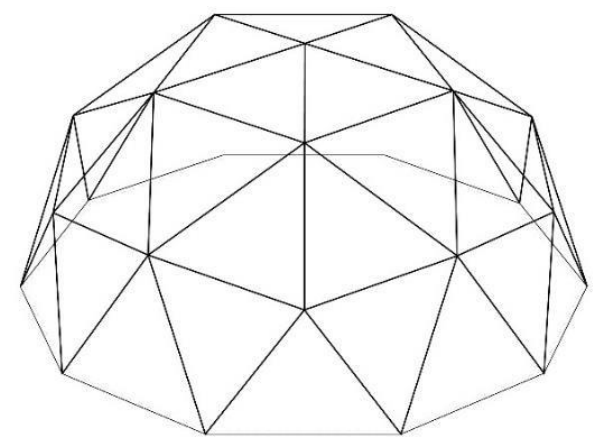

Gambar 21. Geodesic Tent

Sumber: Penulis, 2020

Tipe cabin merupakan pengembangan tipe ridge/frame/wedge yang dibentuk dengan mengubah sudut sisi-sisinya agar menyerupai kabin berbentuk prisma. Dimensi umum $270 \mathrm{~mm}$ x $360 \mathrm{~mm}$ x $220 \mathrm{~mm}$. Tipe kabin umumnya terdiri dari banyak struktur untuk menciptakan kerangka kompleks. Dibuat dari waterproof polyester, nylon dan kanvas yang membalut setiap tiang agar dapat secara kuat menunjang banyak sisi. Tipe kabin mudah untuk membagi ruang dalam dan cocok untuk keluarga karena ruang dalam yang terbentuk cenderung bersifat komunal. Kelebihannya adalah luas, murah, baik untuk kelompok dan ruang kepala yang baik. Kekurangannya berat, rumit untuk dibangun dan biasanya dibuat dengan material berkualitas lebih rendah. 


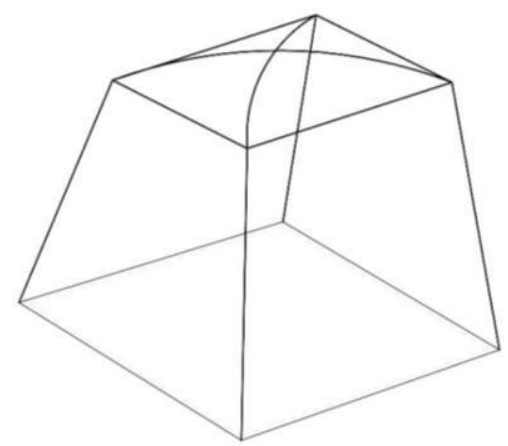

Gambar 22. Cabin Tent

Sumber: Penulis, 2020

Tipe pyramid ialah tipe paling sederhana dari tenda dan terdiri dari hanya sebuah tiang pusat untuk menahan tarikan ke berbagai arah. Dimensi umum $120 \mathrm{~mm}$ x $220 \mathrm{~mm}$ x $100 \mathrm{~mm}$ dan kelipatannya. Kekuatan utama struktur bergantung pada tiang utama, sehingga semakin besar tenda semakin tidak stabil kekuatan strukturnya. Umumnya tenda ini dibuat dari kanvas yang tebal dan tiang pusat yang kuat. Kelebihannya sangat sederhana untuk dibangun, versi modern sangat ringan, stabil pada cuaca buruk. Kekurangannya sedikit ruang vertikal, ruang kepala yang buruk, ruang penyimpanan sangat terbatas, dan biasanya tidak memiliki alas.

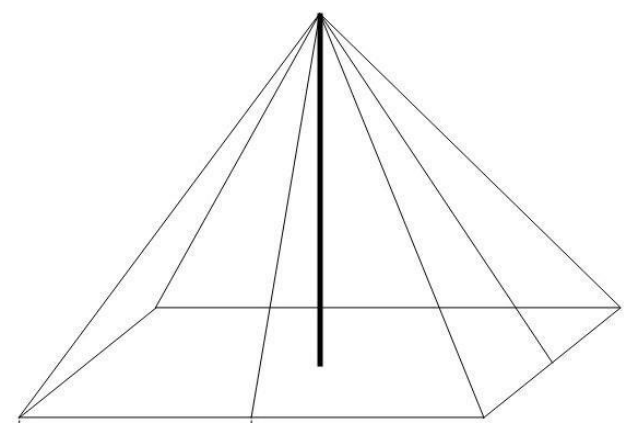

Gambar 23. Pyramid Tent

Sumber: Penulis, 2020

Dengan uraian di atas, jumlah struktur tidak saja mempengaruhi bentuk dan fungsi namun juga kestabilan, harga, pembagian ruang dan jumlah pemakai. Sebagai pernaungan pembagian tipe tidak saja mempertimbangkan tampilan namun juga interaksi sosial, waktu pembangunan dan kondisi iklim karena penggunaan tenda pada gaya hidup nomaden bersifat spesifik. Hal ini sekaligus menjelaskan bahwa meskipun terdapat 3 bentuk dasar, tipe tersebut tidak cukup memenuhi kebutuhan fungsi pengguna karena tujuan penggunaan yang bersifat spesifik. Sifat temporal dan portabel dari tenda menuntut kombinasi, perubahan dan adaptasi yang tinggi terhadap pengguna maupun kondisi lingkungan.

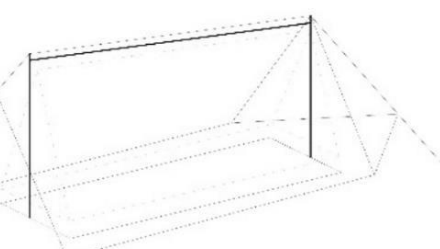

Struktur

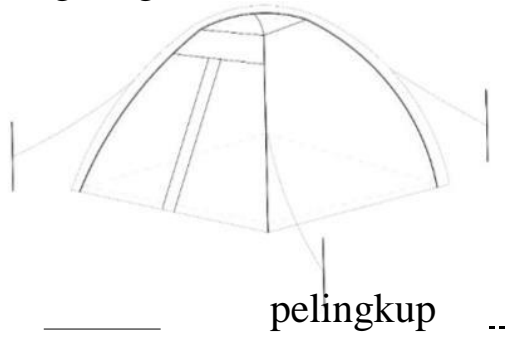

pelingkup

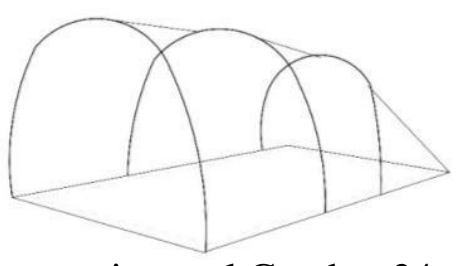

internal Gambar 24.

Ridge Diagram Tent, Dome Tent dan Tunnel Tent

Sumber: Penulis, 2020 
Pembahasan tipe di atas juga sekaligus memberikan penekanan pada hubungan bentuk tenda yang tergantung oleh strukturnya. Tipe dengan 3 bentuk dasar, yakni ridge/frame/wedge, dome dan tunnel sementara yang lainnya merupakan turunan atau pengembangan. Bentuk dan jumlah struktur tidak menyiratkan bahwa sebuah tipe lebih baik dari tipe lainnya, namum mengilustrasikan kelebihan dan kekurangan sebuah model sehingga mengarahkan kepada kecocokan terhadap kebutuhan dan fungsi spesifik. Namun demikian, tidak dapat dipungkiri bahwa 3 tipe dasar juga menjadi tipe umum dan paling populer karena kestabilan dan keajegan tipenya. Pengembangan tipe justru ditujukan untuk menyempurnakan bentuk, struktur dan fungsi tenda sebagai arsitektur pernaungan modern.

Tabel 2. Sampel Variasi Hibrida Tipe dan Detail Sumber: Penulis, 2020

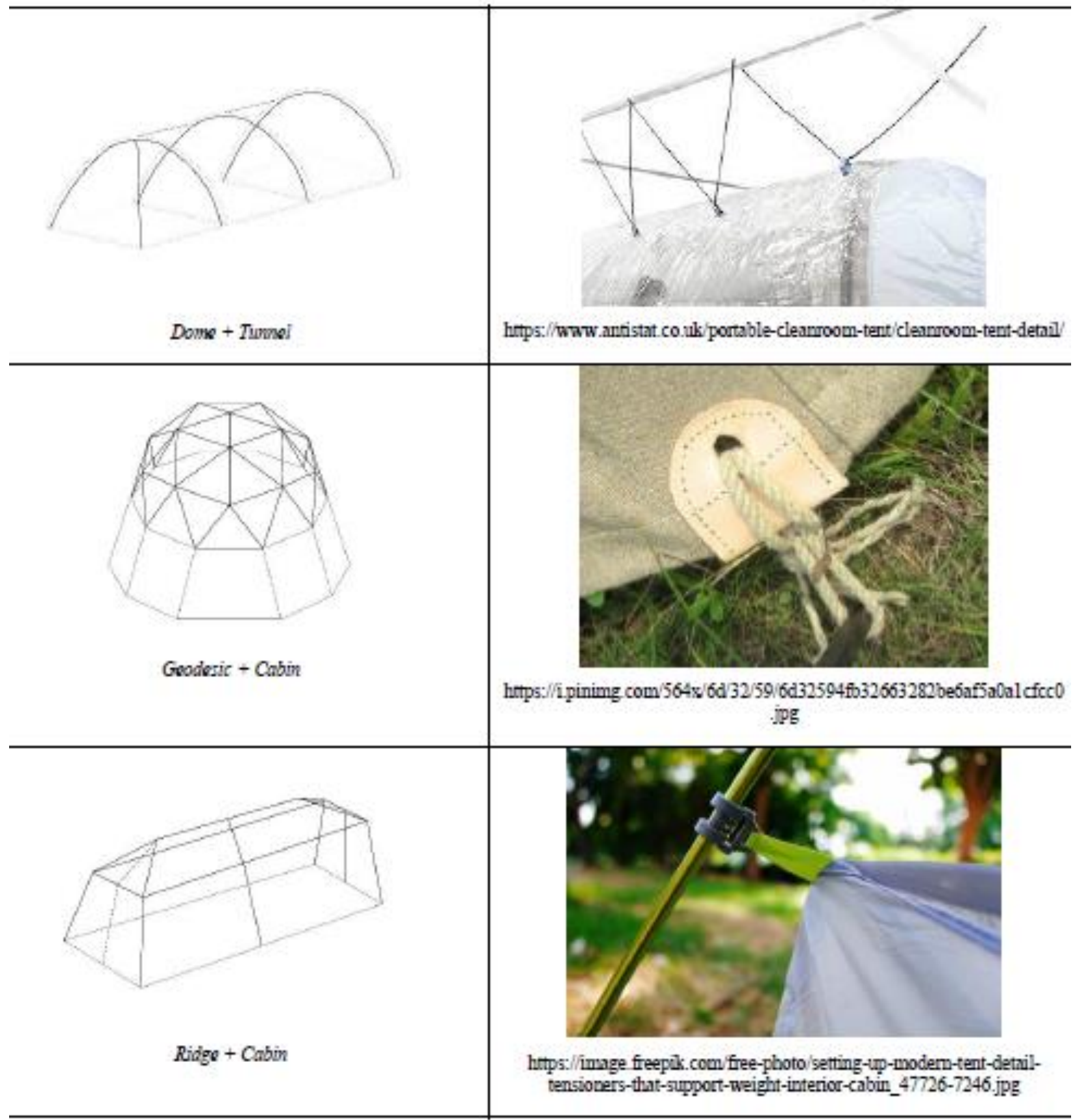




\section{KESIMPULAN}

Tenda adalah salah satu bentuk arsitektur temporal yang masih relevan pada saat ini. Tenda berfungsi sebagai arsitektur pernaungan pada kehidupan nomaden dengan penggunaan ruang bersifat sementara. Penelitian ini menjawab pentingnya mengetahui tipe dasar dan model populer sebagai prioritas pengembangan tenda. Kebutuhan pasar dan permasalahan tenda sebagai pernaungan perlu difokuskan pada bentuk dasar sebagai tipe paling sederhana yang menjadi pilihan khalayak, sementara mengembangkannya menjadi tipe baru atau bahkan hibrida. Sebagai temuan terdapat 3 tipe dasar tenda yang berfokus pada bentuk, pilihan bentuk dikendalikan dengan kompleksitas struktur sementara fungsi yang menjadi kendali pasar. Tiga bentuk dasar merupakan bentuk yang ajeg dan perlu menjadi prioritas pengembangan, ridge/frame/wedge tent, dome tent dan tunnel tent masing masing mewakili kelebihan bentuk, struktur dan fungsi secara berurutan. Pengembangan berfokus pada tipe berpotensi menghasilkan produk yang ekonomis, meningkatkan produktivitas keruangan dan partisipasi/interaksi penggunanya.

\section{UCAPAN TERIMA KASIH}

Terima kasih kepada Lembaga Penelitian dan Pengabdian kepada Masyarakat (LPPM) Universitas Tarumanagara yang telah mendanai penelitian ini.

\section{REFERENSI}

Abuin, E. B. (2004). Kinetic Architecture: A Study in Portable Architecture. Thesis of Master of Architecture. Florida: Florida International University.

Anas, e. a. (2017). Flexible Architecture: Optimization of Technology and Creativity. International Journal Engineering and Technology (IJET) Vol.9 No.3S, 510-520.

Dias, \&. C. (2018). Wearable Health Devices-Vital Sign Monitoring Systems and Technologies. Sensors 2018, 18, 2414. MDPI, 1-28.

Elmokadem, e. a. (April 2018). Kinetic Architecture: Concepts, History and Applications. International Journal of Science and Research (IJSR) Volume 7 Issue 4, 750-758.

Ghaffar, e. a. (2019). Review on Study of Folded Portable Structure. International Research Journal of Engineering and Technology (IRJET) Vol. 6 Issue.3, 1213-1225.

Olga, e. a. (2018). The Millennials: Insights to Brand Behavior for Brand Management Strategies. Journal of Management and Strategy Vol. 9, No. 3, 1-17.

Pyöriä, e. a. (January-March 2017). The Millennial Generation: A New Breed of Labour? Sage Open, 1-14.

Rathi, e. a. (Augustus 2017). Self Sustainable Portable Structure. International Journal of Engineering Science and Computing Vol.7 Issue.8, 14718-14720.

we-a. (2019). https://www.we-a.dk/. Retrieved July 26, 2020, from https://www.we-a.dk/: https://www.we-a.dk/news/2019/3/14/can-architecture-save-the-world 
(halaman ini sengaja dikosongkan) 